\title{
Effects of Global Warming on Vibrio Ecology
}

\section{LUIGI VEZZULLI, ${ }^{1}$ ELISABETTA PEZZATI, ${ }^{1}$ INGRID BRETTAR, ${ }^{2}$ MANFRED HÖFLE, ${ }^{2}$ and CARLA PRUZZO'}

\begin{abstract}
${ }^{1}$ Dipartimento di Scienze della Terra, dell'Ambiente e della Vita (DISTAV), University of Genoa, 16132 Genoa, Italy; ${ }^{2}$ Department of Vaccinology and Applied Microbiology - Microbial Diagnostics, Helmholtz Centre for Infection Research, D 38124 Braunschweig, Germany
\end{abstract}

\begin{abstract}
Vibrio-related infections are increasing worldwide both in humans and aquatic animals. Rise in global sea surface temperature (SST), which is approximately $1^{\circ} \mathrm{C}$ higher now than 140 years ago and is one of the primary physical impacts of global warming, has been linked to such increases. In this chapter, major known effects of increasing SST on the biology and ecology of vibrios are described. They include the effects on bacterial growth rate, both in the field and in laboratory, culturability, expression of pathogenicity traits, and interactions with aquatic organisms and abiotic surfaces. Special emphasis is given to the effect of ocean warming on Vibrio interactions with zooplankters, which represent one of the most important aquatic reservoirs for these bacteria. The reported findings highlight the biocomplexity of the interactions between vibrios and their natural environment in a climate change scenario, posing the need for interdisciplinary studies to properly understand the connection between ocean warming and persistence and spread of vibrios in sea waters and the epidemiology of the diseases they cause.
\end{abstract}

\section{INTRODUCTION}

Vibrios are considered as one of the most abundant culturable bacteria present in the oceans. They are found ubiquitously in a great variety of aquatic environments, from estuary and coastal waters to the deep sea. Vibrios are metabolically versatile microbes, preferring an attached and possibly biofilm existence, in association with animals, plants, and abiotic substrates (1). Habitat preferences have been characterized reasonably well for several Vibrio species and relationships have been established between the presence of certain species and selected environmental factors such as sea surface temperature (SST) and salinity (2). With few exceptions, vibrios grow preferentially in warm $\left(>18^{\circ} \mathrm{C}\right)$, low salinity $(<2.5 \% \mathrm{NaCl})$ waters, and exhibit strong seasonality, being most abundant during summer months when waters are warmer $(\underline{3}, \underline{4}, \underline{5})$. As a consequence, the concentration of these bacteria in seawater and filter feeder organisms, such as oysters (representing a common vehicle of Vibrio transmission to humans), reaches the highest points at these times, posing the greatest threat to human health $(\underline{6}, \underline{7}, \underline{8}, \underline{9})$.

Vibrio-related infections associated with the consumption of contaminated water and seafood are increasing worldwide. In the US, Vibrio parahaemolyticus and Vibrio vulnificus infections have increased since 2000, while the relative rates of infections from other major foodborne pathogens (e.g., Salmonella, Campylobacter, and enterotoxigenic Escherichia coli) have decreased $(10,11,12)$. The number of cholera cases reported to the World Health Organization continues to rise and, for 2011 alone, a total of 589,854 cases and 7,816 deaths were reported by 58 countries. A rise in SST over the past decades is blamed for the observed increase in the incidence of Vibrio infections in humans (13). Warming of the climate system is unequivocal,

Received: 8 October 2014, Accepted: 24 February 2015, Published: 19 June 2015

Editor: Michael Sadowsky, University of Minnesota, St. Paul, MN Citation: Vezzulli L, Pezzati E, Brettar I, Höfle M, Pruzzo C. 2015. Effects of global warming on Vibrio ecology. Microbiol Spectrum 3(3):VE-0004-2014. doi:10.1128/microbiolspec.VE-0004-2014. Correspondence: Carla Pruzzo, carla.pruzzo@unige.it (c) 2015 American Society for Microbiology. All rights reserved. 
with evidence from observations of increases in global average temperatures by nearly $0.8^{\circ} \mathrm{C}$ since the late 19 th century and approximately $0.2^{\circ} \mathrm{C} /$ decade over the past 25 years (14). It has been estimated that global SST is approximately $1^{\circ} \mathrm{C}$ higher now than 140 years ago and is one of the primary physical impacts of climate change $(\underline{15})$.

The scarcity of baseline and epidemiological information at a global level challenges the possibility of assessing the real significance of the recent spate of Vibrio-associated diseases and to properly determine its link with ocean warming. Moreover, difficulty in both carrying out rigorous temporal and spatial sampling over a large scale and translating laboratory or on-deck experiments to the natural environment (16) greatly affects the chance of understanding real consequences of ocean warming on Vibrio spp. occurrence and spread in coastal waters. Hereinafter, major known effects of increasing SST on Vibrio spp. biology and ecology are described. Figure 1 shows most relevant effects of ocean warming on vibrios and zooplankters that represent important environmental reservoir for these bacteria $(16,17)$. In addition, recently published studies carried

FIGURE 1 Simplified scheme of the response of bacteria and zooplankton to ocean warming. Ocean warming deeply influences bacterial growth and biology (e.g., culturability, antigenicity, pathogenicity, and gene expression) and zooplankton development, phenology, size, structure, and poleward movements. An increasing SST also triggers algal blooms that in turn promote an increase in zooplankters feeding on algae. Consequences of all the above include a higher association of vibrios to zooplankters (also due to a temperaturedependent higher expression of specific ligands), introduction of new Vibrio species/clones in new areas, and spread of associated human and animal diseases. doi:10.1128/microbiolspec .VE-0004-2014.f1

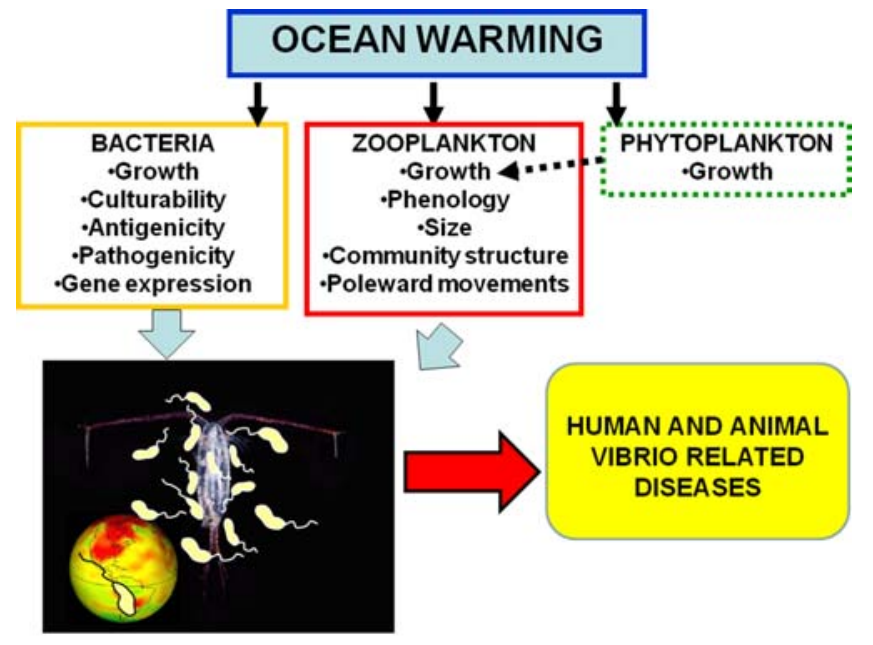

out in the southern North Sea are summarized as they provided the first experimental evidence for a positive and significant relationship between SST and Vibrio occurrence over a multidecadal time scale (17).

\section{VIBRIO INFECTIONS IN HUMANS AND AQUATIC ORGANISMS: RELATIONSHIPS WITH INCREASING SST}

It is becoming more and more evident that, although different factors linked to both climate and human activities are involved in driving the incidence of Vibriorelated diseases, the increase in SST is one of the major triggering determinants in most examined scenarios. A geographical transition in terms of disease into nonendemic regions can be observed, especially in temperate and cold regions of the world, which are the most affected by global warming $(18,19)$. V. parahaemolyticus O6: K18 infections occurred in Alaska in 2004 in coincidence with the arrival of warm waters that have exceeded the limit of 40 degrees latitude, usually not crossed during the summer (11). Satellite images have identified the Pacific coast of the US as the most likely origin of these warm waters. A similar scenario was observed during an outbreak of infection by V. parahaemolyticus in Galicia in 1999 (19). The emergence of the cases has been associated with a new serotype (O4: K11), and was coincident with the arrival of warm tropical waters in the coast of Galicia, and their permanence in the region. In northwest European countries, the number of reported Vibrio-related infections associated with recreational bathing has increased within the last decades. For instance, during the hot summer of 2006, wound infections linked to contact with Baltic and North Sea waters were reported from Germany (V. vulnificus) (20), southeast Sweden (V. cholerae non-O1/O139) (21), The Netherlands (V.alginolyticus) (22), and Denmark (V. alginolyticus and V. parahaemolyticus) (23). In Peru, climate events, such as El Niño, have been implicated in the geographical expansion of the V. parahaemolyticus outbreaks in 1997 to 1998, as a result of the southward shift of warm, low salinity water surges (11). Where cholera is endemic, cases tend to demonstrate distinct seasonal trends $(\underline{24}, 25)$. These patterns are strongly related to the ecology of $V$. cholerae in the environment, where high numbers are observed during times of warm-water temperatures and zooplankton blooms (24). A study by Huq et al. (26) showed that water temperature is directly correlated with cases of cholera in Bakerganj, the southernmost site included in the study, having the most direct influence 
from the Bay of Bengal, where most of the initial cases of cholera occurred, including the outbreak of the then newly recognized serotype O139 in 1992 (27). A detailed analysis of existing data indicated that the interannual occurrence of cholera in Bangladesh, and the area surrounding the Bay of Bengal, is related to El Niño-Southern Oscillation (ENSO) $(28,29)$. In South America, where the disease has become endemic since its reemergence in 1991, cases are concentrated in the austral summer months (January and February) (30, 24). A Poisson regression model has been used to analyze the possible association between the cholera rates in southeastern Africa and the annual variability of air temperature and SST at regional and hemispheric scales for the period 1971 to 2006. The results showed that the annual mean air temperature and SST at the local scale, as well as anomalies at hemispheric scales, had a significant impact on the cholera incidence during the study period (31). The use of remote sensing imagery to gather data on SST and sea surface height uncovered a significant correlation of temperature with cholera outbreaks in Bangladesh and in South America (32).

In spite of numerous reports suggesting that SST increase is one of the most important drivers of cholera and other human vibriosis worldwide, other potential climate-driven factors must be taken into account (e.g., droughts and floods, sea surface height, salinity, $\mathrm{pH}$, and river discharge). This is suggested by recent observations that vibriosis have increased significantly in the USA in the last decade $(12,33)$ and also in areas where long-term coastal temperature trends are weakly cooling or not significant \{South Atlantic Bight $\left[-0.1^{\circ} \mathrm{C} \pm 0.3^{\circ} \mathrm{C}(100\right.$ years $\left.)^{-1}\right]$ and off Florida $\left.\left[-0.3^{\circ} \mathrm{C} \pm 0.2^{\circ} \mathrm{C}(100 \text { years })^{-1}\right]\right\}$ (34).

In marine animals, several disease outbreaks have been associated with a rise in SST and climatic events such as ENSO (28). This is clearly evident among corals, which are known to bleach in response to a range of environmental stresses (35). For instance, the coral bleaching of 1998 on the Great Barrier Reef was the most geographically extensive and severe in recorded history, causing significant mortality of coral reefs worldwide $(35, \underline{36})$. The stress for many of these coral reef systems seems to be the result of long-term exposure to unusually high water temperatures as a consequence of a prolonged ENSO event. Such climate-mediated, physiological stresses may compromise host resistance and increase frequency of opportunistic diseases due, among others, to vibrios (35). In the Mediterranean Sea, coral bleaching of Oculina patagonica was promoted by Vibrio shiloi when SST rose above $25^{\circ} \mathrm{C}$ (37). Another example comes from studies on mass mortality events of gorgonians (Paramuricea clavata) in the Mediterranean Sea (38). Phylogenetic and phenotypic analysis of Vibrio isolates associated with healthy and diseased $P$. clavata colonies collected during mortality episodes showed that these bacteria are significantly more abundant in diseased than in healthy corals, including the species Vibrio coralliilyticus, which is only found in diseased organisms. Results of infection studies conducted in aquaria suggested that long-lasting high temperature values and trophic conditions can predispose gorgonians to infections by vibrios, whose concentration in ambient water is triggered by the temperature increase. Other studies conducted to define environmental determinants affecting the capability of Vibrio harveyi to induce mortality in a wide variety of marine animal species showed a strong positive correlation between sea temperature and abalone mortality caused by this pathogen on the basis of 5 years' worth of data (2003 to 2007) (39).

Overall, predicted global warming leading to longlasting hot summer periods represents a major threat to the survival of invertebrates in temperate areas due to increased sensitivity to pathogenic/opportunistic infections coupled with an increased concentration of vibrios in surrounding waters and an increased expression of virulence factors (40). It is hypothesized that the effects of climate change on both aquatic animals and (opportunistic) pathogens will be superimposed onto the effects of other stressors in ecosystems, such as those deriving from human activity (e.g., pollution, shipping, fishing and recreational activities), leading to habitat and bio-

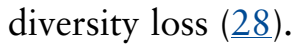

\section{EFFECT OF INCREASING SST ON VIBRIO GROWTH AND BIOLOGY: FIELD AND IN VITRO EVIDENCE}

The density of vibrios is related to seasonal variations and maximal Vibrio concentration is recorded in water above a temperature of approximately $10^{\circ} \mathrm{C}$ to $17^{\circ} \mathrm{C}$, depending on species (41). Field studies conducted worldwide over the last 40 years have shown such a relationship $(\underline{42}, \underline{43}, \underline{44}, \underline{45})$. As an example, results from different studies conducted over the period from 1995 to 2004 along the central-northern Italian Adriatic coast $(46,47,48,49)$ showed that culturable vibrios (mainly the species Vibrio alginolyticus) were abundant in this area during the warmest months, when SST ranged from about $18^{\circ} \mathrm{C}$ to about $25^{\circ} \mathrm{C}$. They were not present or were present in very low concentration during winter. 
Elevated SST can also have an indirect effect on Vibrio growth in coastal waters, as suggested for the first time by Cockburn and Cassanos (50). Sunlight, temperature, and nutrients all influence the growth of phytoplankton and aquatic plants, which, in turn, alter the dissolved $\mathrm{O}_{2}$ and $\mathrm{CO}_{2}$ content and, therefore, the $\mathrm{pH}$ of the surrounding water (24). It was proposed that in hot, dry weather, algae could raise the $\mathrm{pH}$ of the water so high that $V$. cholerae is favored over other organisms and reach infectious dose levels (미).

Field observations are consistent with results of in vitro experiments showing that temperature is one of the main factors influencing growth rates of vibrios. For instance, in V. cholerae, an exponential relationship in growth rate was observed for the interval from $15^{\circ} \mathrm{C}$ to $37^{\circ} \mathrm{C}(\underline{51})$. In V. vulnificus, cells growing at $23^{\circ} \mathrm{C}$ and $13^{\circ} \mathrm{C}$ doubled every $3 \mathrm{~h}$ and $13.1 \mathrm{~h}$, respectively (52). In Vibrio splendidus, a 4- to 6-fold decrease in bacterial growth was observed as temperatures decreased from $15^{\circ} \mathrm{C}$ to $0^{\circ} \mathrm{C}(\underline{53})$. Besides temperature, salinity and $\mathrm{pH}$ affect the growth rate of vibrios, as in the case of $V$. cholerae for which optimal salinity for growth is between $0.5 \%$ and $2.5 \%$. However, it can also exist and prosper in freshwater, with sufficient dissolved organic matter present, and can grow at salinities values up to $4.5 \%(\underline{2})$.

In addition to cell growth rate, SST influences bacterial culturability, antigenicity, and pathogenicity. In coastal water, during winter months, when SST dips below the preferred range, most vibrios can enter a dormant state known as "viable but nonculturable" (VBNC) (54, 55). Other factors, both chemical and environmental, which have been reported to induce the VBNC state, are diverse and numerous. They include nutrient starvation, elevated or lowered osmotic concentrations, oxygen concentrations, heavy metals, and even exposure to white light (56). In vitro and in vivo studies showed that VBNC cells continue to be metabolically active, retain pathogenic potential but do not grow and do not form a colony on traditional culture media (57). VBNC bacteria can be detected in biological samples by culture-independent methods only (e.g., immunofluorescence, PCR) (58, 59, 60). Under favorable conditions (such as a rise in temperature), reversion from the VBNC to the culturable state can take place $(56,61)$.

Concerning antigenicity, microcosm experiments have shown that temperature and salinity are important factors in $V$. cholerae conversion from non-O1 to $\mathrm{O} 1$ serogroup (62). Serogroup conversion was shown to be consequent to chitin-induced natural transformation occurring within a community of bacteria living on a chitin surface (63). Increased expression of known and putative virulence-associated traits was correlated with increased temperature in human $(V$. cholerae, $V$. vulnificus, and $V$. parahaemolyticus) and animal (V. coralliilyticus, V. shiloi) species $(64,65,66)$. At high summer seawater temperatures, $V$. shilo $i$, the causative agent of bleaching of $O$. patagonica, produces an adhesin that allows it to adhere to a beta-galactosidecontaining receptor in the coral mucus, penetrate into the coral epidermis, multiply intracellularly, differentiate into a VBNC state, and produce toxins that inhibit photosynthesis and lyse the symbiotic zooxanthellae (40). In $V$. cholerae, temperature regulates transcription of tox $T$, a gene encoding the regulatory protein ToxT that directly activates transcription of virulence factors, including cholera toxin (CT) and the toxin-coregulated pilus (TCP) (67).

\section{EFFECT OF INCREASING SST ON VIBRIO INTERACTIONS WITH LIVING AND NONLIVING MARINE SUBSTRATES}

The ecology of vibrios in coastal waters is intimately coupled with their attachment to biotic and abiotic surfaces; these interactions are also important for Vibrio transmission from the aquatic environment to humans (24). Vibrios are found associated with protozoa, plankton organisms (e.g., copepods), plants, bivalves, fishes, water birds, and a variety of abiotic substrates, such as detrital chitin and inorganic particles (68). Among variables affecting such interactions, temperature seems to play an important role. For instance, it has been shown that attachment of $V$. alginolyticus to chitin particles progressively increases from about $65 \%$ to about $80 \%$ of the inoculum as temperature increases from $5^{\circ} \mathrm{C}$ to $20^{\circ} \mathrm{C}(\underline{69})$. A study conducted by Long et al. (므) showed that interspecies antagonistic interactions influence particle colonization by $V$. cholerae. Autochthonous bacteria appear to become less inhibitory against this pathogen at elevated temperatures such as those measured during ENSO and monsoonal events. It is hypothesized that SST increase due to changes in global climate can reduce competitiveness from other autochthonous microbes, contributing to increasing abundance and geographic spread of $V$. cholerae. In this frame, another study conducted by Rypien et al. (71) on bacteriabacteria antagonism in a coral Montastrea annularisassociated microbial community, reported that several potential pathogens are present in the microbial community of apparently healthy corals, and a measurable percentage (about $12 \%$ ) of isolates is able to inhibit the 
growth of the coral pathogen V. shiloi. Elevated temperatures generally diminished levels of antagonistic interactions among coral-associated bacteria (71) suggesting that, in this case too, ocean warming might contribute to disease onset, reducing the inhibitory activity exerted by harmless bacteria towards pathogens.

$V$. cholerae interaction with copepods deserves particular attention as these zooplankton organisms are the most (or one of the most) important environmental reservoir for the bacterium, favoring its persistence and spread in oceans, and also serving as vector of infection (68). Huq et al. (72) proposed that once cells of $V$. cholerae attach to zooplankton, they are protected from the external environment and begin to proliferate. The chitin exoskeleton of a single colonized copepod has been shown to contain up to $10^{4}$ cells of $V$. cholerae $(73)$, thus providing the required infectious dose for clinical cholera, ranging from $10^{4}$ to $10^{11}$ bacteria, depending on the strain and the infected host (74). In the VBNC state, bacteria maintain the capability to adhere to chitin particles and copepods, although at a lower degree compared to actively growing controls $(75)$. Interactions between vibrios and copepods are affected by environmental variables. Salinity of $1.5 \%$ and temperatures ranging from $25^{\circ} \mathrm{C}$ to $30^{\circ} \mathrm{C}$ have been shown to be important in influencing the attachment of $V$. cholerae to copepods $(76, \underline{77})$. A possible explanation for this comes from recent studies $(\underline{78}, \underline{79})$ evaluating the expression of two major $V$. cholerae adhesins involved in interactions with zooplankters and chitin substrates $[\mathrm{N}$-acetyl glucosamine-binding protein $\mathrm{A}(\mathrm{GbpA})$ and mannose-sensitive hemagglutinin (MSHA)] in aquatic microcosms. Experiments conducted at different temperatures $\left(15^{\circ} \mathrm{C}, 20^{\circ} \mathrm{C}\right.$, and $\left.25^{\circ} \mathrm{C}\right)$, matching the seasonal temperature range of temperate marine environments, showed a significant increase in expression level of both adhesins at $25^{\circ} \mathrm{C}$. This suggests that temperature can play a role in promoting $V$. cholerae colonization of environmental surfaces via an enhanced expression of MSHA and GbpA $(\underline{78}, \underline{79})$.

The recognized biological interaction between vibrios (mainly V. cholerae) and zooplankters makes the study of the response of these marine organisms to ocean warming crucial for understanding the effects of climate change on the persistence and spread of Vibrio bacteria in the ocean. Conditions favorable for multiplication of copepods and related chitinous zooplankton species are expected to result in an increase in the number of $V$. cholerae and other vibrios in the aquatic environment (2). Changes in abundance and spread of warm-water zooplankton species can be observed as a direct conse- quence of heating of the ocean's surface waters. Moreover, elevated water temperatures are known to trigger algal blooms that, in turn, promote the increase in zooplankton grazers feeding on algae (무). Other major direct impacts of an increasing SST are manifest as size reduction, earlier timing of important life cycle events, changes in community structure, and poleward movements in the distribution of individual species and assemblages $(\underline{81}, \underline{82}, \underline{83}, \underline{84})$. In the eastern North Atlantic and on the European shelf, due to latitudinal movement of warm and tropical waters, strong biogeographical shifts in copepod assemblages occurred during the last 50 years, with a poleward extension of more than 10 degrees latitude (more than $1,000 \mathrm{~km}$ ) for warm-water species and a decrease in the number of colder water species (82). Allochthonous plankton organisms serve as vehicles for the introduction of new Vibrio species/clones in new areas $(\underline{11}, 19, \underline{85})$. Such invasive microorganisms may become endemic if environmental conditions are favorable for their establishment $(11, \underline{85})$. It must be taken into consideration that differences may exist in the capability of different Vibrio species and clones to colonize various zooplankton species and organisms at different life stages. At present, very few comparative measures exist to evaluate this possibility and these are restricted to only a few plankton species under a limited range of the possible environmental conditions (ㅁ6).

\section{LONG-TERM EFFECTS OF OCEAN WARMING ON THE VIBRIO COMMUNITY IN THE SOUTHERN NORTH SEA: A CASE STUDY}

Despite the fact that statistically significant empirical relationships have been established between the presence of vibrios and SST and other environmental factors (2), gaps still exist that preclude conclusive evidence regarding the effect of ocean warming on Vibrio occurrence and spread. A possible explanation for this is the lack of comparable data, conducted over a large spatial and temporal scale. To fill in this gap, at least in part, a study was recently conducted to analyze long-term relationships between Vibrio occurrence and climatic variables through retrospective molecular analysis of samples collected by the Continuous Plankton Recorder (CPR) survey in the North Sea (17), where, in recent years, an unexpected increase in the number of bather infections associated with vibrios was reported (see above, and 20, 21, 22, 23).

The CPR archive represents one of the largest spatialtemporal collection of marine biological samples in the 
world (http://www.sahfos.ac.uk). The CPR is a plankton sampling instrument designed to be towed from merchant ships, or ships of opportunity, at a depth of approximately $10 \mathrm{~m}$ on their normal sailings (87). Water passes through the CPR and plankton is filtered onto a slow-moving band of silk (of $270 \mu \mathrm{m}$ mesh size) that is covered by a second silk, then spooled into a storage tank containing formaldehyde. On return to the laboratory, the silk is removed from the mechanism and divided into samples. As plankton represents the largest environmental reservoir for vibrios in the aquatic environment, it is reasonable that the CPR system, capturing plankton and particles, also captures a significant fraction of associated vibrios. Based on this rationale, a study was planned for long-term molecular enumeration of vibrios associated with plankton in formaldehydefixed CPR samples collected off the Rhine estuary from 1961 to 2006 and off the Humber estuary from 1965 to 2006 (17). All samples analyzed in this study were collected in August along an $18.5 \mathrm{~km}$ tow corresponding to $3 \mathrm{~m}^{3}$ of filtered seawater for each sample. The total area sampled, during the 45 years period, was about $3,000 \mathrm{~km}^{2}$ for both sites. To analyze formalin-fixed samples, a method was developed to extract good quality genomic DNA to be used for the evaluation of the relative proportion of plankton-associated vibrios (Vibrio relative abundance index-VAI) by real-time PCR. VAI was defined as the ratio of Vibrio spp. cells to the total number of bacterial cells assessed using genus-specific and universal primers, respectively.

A long-term increase in the relative abundance of vibrios was observed in CPR samples collected off the Rhine estuary that showed a positive and statistically significant correlation with SST; this correlation was not observed in samples collected off the Humber estuary. Such different results for the two areas can be related to the generally higher summer SST values recorded off the Rhine estuary compared to the Humber estuary. In fact, only off the Rhine area did SST in summer periods exceeded $18^{\circ} \mathrm{C}$, thus favoring Vibrio growth. A nonparametric multiple regression analysis ( $\underline{88})$, comprising pooled VAI data, the number of total copepods, and phytoplankton color (an index of phytoplankton biomass), calculated for the same areas and period, showed that, in the North Sea, SST and the number of total copepods explained $50 \%$ of the variance in the Vibrio data $(\mathrm{p}<0.05)$, with SST alone explaining $45 \%$ of the variance. These findings supported evidence from previous studies that an increase in temperature might enhance not only Vibrio growth rates but also their capability to attach to and multiply on plankton (76). The analysis of the composition of the bacterial community in selected CPR samples by $16 \mathrm{~S}$ rDNA pyrosequencing showed that particle-associated vibrios, including the human pathogen $V$. cholerae, have increased in prevalence from 1961 to 2006 in the coastal waters of the southern North Sea (17). These findings provided the first experimental evidence that global warming is having a strong impact on the marine bacterial community.

\section{CONCLUSIONS}

Vibrios, for their ubiquity in aquatic environments, flexible physiology, and thermal dependence, represent a very useful model to study the connection between ocean warming and persistence and spread of waterborne pathogens in sea waters and the epidemiology of the diseases they cause. However, in spite of numerous reports, the biocomplexity of interactions between these bacteria and their natural environment in a climate change scenario is still poorly understood. To clarify these aspects, further studies must be planned, including (i) comparative field observations on the occurrence and spread of these bacteria on long temporal and spatial scale (e.g., retrospective analyses and remote sensing measurements). (ii) Studies on Vibrio spp. interactions with their aquatic reservoirs, including different species and life stages, both in the laboratory and in the field, in different environmental and climatic scenarios. (iii) Studies on Vibrio ecology in less-explored aquatic matrices (e.g., sediment); and (iv) implementation of all the above with results from the analysis of the influence of climate change on host susceptibility and exposure patterns. The success of these interdisciplinary approaches will be also dependent on the creation of an international collaborative research network to develop a freely accessible database that would allow data to be analyzed and interpreted $(\underline{88}, \underline{89})$. These studies, as a whole, are expected to allow the construction of models and the development of measures to predict, prevent, and control Vibrio-related diseases.

\section{ACKNOWLEDGMENTS}

This work was partially supported by "Ministero dell'Università e della Ricerca Scientifica e Tecnologica" and the FP7-European Project Aquavalens (Grant Agrement 311846).

Conflicts of interest: We declare no conflicts.

\section{REFERENCES}

1. Grimes DJ, Johnson CN, Dillon KS, Flowers AR, Noriea NF 3rd, Berutti T. 2009. What genomic sequence information has revealed about Vibrio ecology in the ocean-a review. Microb Ecol 58:447-460.

2. de Magny GC, Colwell RR. 2009. Cholera and climate: a demonstrated relationship. Trans Amer Clin Climatol Ass 120:119-128. 
3. Baross J, Liston J. 1970. Occurrence of Vibrio parahaemolyticus and related hemolytic vibrios in marine environments of Washington State. Appl Microbiol 20:179-186.

4. Kaneko T, Colwell RR. 1973. Ecology of Vibrio parahaemolyticus in Chesapeake Bay. J Bacteriol 113:24-32.

5. DePaola A, Hopkins LH, Peeler JT, Wentz B, McPhearson RM. 1990. Incidence of Vibrio parahaemolyticus in U.S. coastal waters and oysters. Appl Environ Microbiol 56:2299-2302.

6. Parveen S, Hettiarachchi KA, Bowers JC, Jones JL, Tamplin ML, McKay R, Beatty W, Brohawn K, Dasilva LV, Depaola A. 2008. Seasonal distribution of total and pathogenic Vibrio parahaemolyticus in Chesapeake Bay oysters and waters. Int J Food Microbiol 128:354-361.

7. Lhafi SK, Kuhne M. 2007. Occurrence of Vibrio spp. in blue mussels (Mytilus edulis) from the German Wadden Sea. Int J Food Microbiol 116:297-300.

8. Paranjpye R, Hamel OS, Stojanovski A, Liermann M. 2012. Genetic diversity of clinical and environmental Vibrio parahaemolyticus strains from the Pacific Northwest. Appl Environ Microbiol 78:8631-8638.

9. DePaola A, Nordstrom JL, Bowers JC, Wells JG, Cook DW. 2003. Seasonal abundance of total and pathogenic Vibrio parahaemolyticus in Alabama oysters. Appl Environ Microbiol 69:1521-1526.

10. Centers for Disease Control and Prevention (CDC). 2009. Preliminary FoodNet Data on the incidence of infection with pathogens transmitted commonly through food - 10 States, 2008. MMWR Morb Mortal Wkly Rep 58:333-337.

11. Martinez-Urtaza J, Bowers JC, Trinanes J, DePaola A. 2010. Climate anomalies and the increasing risk of Vibrio parahaemolyticus and Vibrio vulnificus illnesses. Food Res Internat 43:1780-1790.

12. Newton A, Kendall M, Vugia DJ, Henao OL, Mahon BE. 2012. Increasing rates of vibriosis in the United States, 1996-2010: review of surveillance data from 2 systems. Clin Infect Dis 54:391-395.

13. Baker-Austin C, Trinanes JA, Taylor NGH, Hartnell R, Siitonen A, Martinez-Urtaza J. 2013. Emerging Vibrio risk at high latitudes in response to ocean warming. Nature Clim Change 3:73-77.

14. IPCC. 2007. Climate Change 2007: Synthesis Report. IPCC, Geneva, Switzerland.

15. NOAA. 2012. Extended Reconstructed Sea Surface Temperature (ERSST.v3b). National Climatic Data Center, Asheville, NC.

16. Vezzulli L, Colwell RR, Pruzzo C. 2013. Ocean warming and spread of pathogenic vibrios in the aquatic environment. Microb Ecol 65:817825 .

17. Vezzulli L, Brettar I, Pezzati E, Reid PC, Colwell RR, Höfle MG, Pruzzo C. 2012. Long-term effects of ocean warming on the prokaryotic community: evidence from the vibrios. ISME J 6:21-30.

18. Lima FP, Wethey DS. 2012. Three decades of high-resolution coastal sea surface temperatures reveal more than warming. Nat Commun 3:704. 19. Baker-Austin C, Stockley L, Rangdale R, Martinez-Urtza J. 2010. Environmental occurrence and clinical impact of Vibrio vulnificus and Vibrio parahaemolyticus: a European perspective. Environ Microbiol Rep 2:7-18.

20. Frank C, Littman M, Alpers K, Hallauer J. 2006. Vibrio vulnificus wound infections after contact with the Baltic Sea, Germany. Euro Surveill 11:E060817.1.

21. Andersson Y, Ekdahl K. 2006. Wound infections due to Vibrio cholerae in Sweden after swimming in the Baltic Sea, summer 2006. Euro Surveill 11:E060803.2.

22. Schets FM, Van den Berg HHJL, Demeulmeester AA, Van Dijk E, Rutjes SA, Van Hooijdonk HJP, de Roda Husman AM. 2006. Vibrio alginolyticus infections in the Netherlands after swimming in the North Sea. Euro Surveill 11:E061109.3.

23. Andersen PH. 2006. Infections with seawater bacteria. EPI-NEWS $1: 26-32$.
24. Lipp EK, Huq A, Colwell RR. 2002. Effects of global climate on infectious disease: the cholera model. Clin Microbiol Rev 15:757-770.

25. Lobitz B, Beck L, Huq A, Wood B, Fuchs G, Faruque AS, Colwell R. 2000. Climate and infectious disease: use of remote sensing for detection of Vibrio cholerae by indirect measurement. Proc Nat Acad Sci USA 97:1438-1443.

26. Huq A, Sack RB, Nizam A, Longini IM, Nair GB, Ali A, Morris JG Jr, Khan MN, Siddique AK, Yunus M, Albert MJ, Sack DA, Colwell RR. 2005. Critical factors influencing the occurrence of Vibrio cholerae in the environment of Bangladesh. Appl Environ Microbiol 71:46454654 .

27. Sedas VT. 2007. Influence of environmental factors on the presence of Vibrio cholerae in the marine environment: a climate link. J Infect Dev Ctries 1:224-41.

28. Marcogliese DJ. 2008. The impact of climate change on the parasites and infectious diseases of aquatic animals. Rev Sci Tech Off Int Epiz 27:467-484.

29. Pascual M, Bouma MJ, Dobson AP. 2002. Cholera and climate: revisiting the quantitative evidence. Microbes Infect 4:237-245.

30. Kaper JB, Morris JG Jr, Levine MM. 1995. Cholera. Clin Microbiol Rev 8:48-86.

31. Paz S. 2009. Impact of temperature variability on cholera incidence in southeastern Africa, 1971-2006. Ecohealth 6:340-345.

32. de Magny GC, Murtugudde R, Sapiano MRP, Nizam A, Brown CW, Busalacchi AJ, Yunuse M, Nair GB, Gil AI, Lanata CF, Calkinsi J, Manna B, Rajendran K, Bhattacharya MK, Huq A, Sack RB, Colwell RR. 2008. Environmental signatures associated with cholera epidemics. Proc Nat Acad Sci USA 105:17676-17681.

33. Weis KE, Hammond RM, Hutchinson R, Blackmore CG. 2011. Vibrio illness in Florida, 1998-2007. Epidemiol Infect 139:591-598.

34. Shearman RK, Lentz SJ. 2012. Long-term sea surface temperature variability along the U.S. East Coast. J Phys Oceanogr 40:10041017.

35. Harvell, CD, Kim K, Burkholder J M, Colwell RR, Epstein PR, Grimes DJ, Hofmann EE, Lipp EK, Osterhaus DME, Overstreet RM, Porter JW, Smith GW, Vasta GR. 1999. Emerging marine diseasesclimate links and anthropogenic factors. Science 285:1505-1510.

36. Baird H, Marshall PA. 1998. Mass bleaching of corals on the Great Barrier Reef. Coral Reefs 17:376.

37. Rosenberg E, Falkovitz L. 2004. The Vibrio shiloi/Oculina patagonica model system of coral bleaching. Annu Rev Microbiol 58:143-159.

38. Vezzulli L, Previati M, Pruzzo C, Marchese A, Bourne DG, Cerrano C. 2010. Vibrio infections triggering mass mortality events in a warming Mediterranean Sea. Environ Microbiol 12:2007-2019.

39. Fukui Y, Saitoh S-I, Sawabe T. 2010. Environmental determinants correlated to Vibrio harveyi-mediated death of marine gastropods. Environ Microbiol 12:124-133.

40. Rosenberg E, Ben-Haim Y. 2002. Microbial diseases of corals and global warming. Environ Microbiol 4:318-326.

41. Smolikova LM, Somova AG, Medinskiŭ GM, Pashentseva NF, Orekhova IM. 1977. Seasonal dynamics of the abundance of vibrios and related microorganisms in the Don River. Zh Mikrobiol Epidemiol Immunobiol 12:29-33.

42. Hsieh JL, Fries JS, Noble RT. 2008. Dynamics and predictive modelling of Vibrio spp. in the Neuse river estuary, North Carolina, USA. Environ Microbiol 10:57-64.

43. Randa MA, Polz MF, Lim E. 2004. Effects of Temperature and Salinity on Vibrio vulnificus population dynamics as assessed by quantitative PCR. Appl Environ Microbiol 70:5469-5476.

44. Oberbeckmann S, Fuchs BM, Meiners M, Wichels A, Wiltshire KH, Gerdts G. 2012. Seasonal dynamics and modeling of a Vibrio community in coastal waters of the North Sea. Microb Ecol 63:543-551. 
45. Thompson JR, Randa MA, Marcelino LA, Tomita-Mitchell A, Lim E, Polz MF. 2004. Diversity and dynamics of a North Atlantic coastal Vibrio community. Appl Environ Microbiol 70:4103-4110.

46. Montanari MP, Pruzzo C, Pane L, Colwell RR. 1999. Vibrios associated with plankton in a coastal zone of the Adriatic Sea (Italy). FEMS Microbiol Ecol 29:241-247.

47. Barbieri E, Falzano L, Fiorentini C, Pianitti A, Baffone W, Fabbri A, Matarrese P, Caisere A, Katouli M, Kühn I, Mölby F, Bruscolini F, Donelli G. 1999. Occurrence, diversity, and pathogenicity of halophilic Vibrio spp. and non O1 Vibrio cholerae from estuarine waters along the Italian Adriatic Coast. Appl Environ Microbiol 65:2748-2753.

48. Baffone W, Tarsi R, Pane L, Campana R, Repetto B, Mariottini GL, Pruzzo C. 2006. Detection of free-living and plankton-bound vibrios in coastal waters of the Adriatic Sea (Italy) and study of their pathogenicityassociated properties. Environ Microbiol 28:1299-1305.

49. Covazzi Harriague A, Brino MD, Zampini M, Albertelli G, Pruzzo C, Misic C. 2008. Vibrios in association with sedimentary crustaceans in three beaches of the northern Adriatic Sea (Italy). Mar Pollut Bull 56:574-579. 50. Cockburn TA, Cassanos JG. 1960. Epidemiology of endemic cholera. Public Health Rep 75:791-803.

51. Kirschner AK, Schlesinger J, Farnleitner AH, Hornek R, Süss B, Golda B, Herzig A, Reitner B. 2008. Rapid growth of planktonic Vibrio cholerae non-O1/non-O139 strains in a large alkaline lake in Austria: dependence on temperature and dissolved organic carbon quality. Appl Environ Microbiol 74:2004-2015.

52. McGovern VP, Oliver JD. 1995. Induction of cold-responsive proteins in Vibrio vulnificus. J Bacteriol 177:4131-4133.

53. Delaney MP. 2003. Effects of temperature and turbulence on the predator-prey interactions between a heterotrophic flagellate and a marine bacterium. Microb Ecol 45:218-225.

54. Coutard F, Crassous P, Droguet M, Gobin E, Colwell RR, Pommepuy M, Hervio-Heath D. 2007. Recovery in culture of viable but nonculturable Vibrio parahaemolyticus: regrowth or resuscitation? ISME J 1:111-120.

55. Colwell RR. 2000. Viable but nonculturable bacteria: a survival strategy. J Infect Chemother 6:121-125.

56. Oliver JD. 2010. Recent findings on the viable but nonculturable state in pathogenic bacteria. FEMS Microbiol Rev 34:415-425.

57. Oliver JD. 2005. The viable but nonculturable state in bacteria. J Microbiol 43:93-100.

58. Huq A, Colwell RR, Rahman R, Ali A, Chowdhury MAR, Parveen S, Sack DA, Russek-Cohen E. 1990. Detection of Vibrio cholerae O1 in the aquatic environment by fluorescent-monoclonal antibody and culture methods. Appl Environ Microbiol 56:2370-2373.

59. Rivera ING, Lipp EK, Gil A, Choopun N, Huq A, Colwell Rr. 2003. Method of DNA extraction and application of multiplex polymerase chain reaction to detect toxigenic $V$. cholerae $\mathrm{O} 1$ and $\mathrm{O} 139$ from aquatic ecosystems. Environ Microbiol 5:599-606.

60. Kelly MT, Stroh EM. 1988. Occurrence of Vibrionaceae in natural and cultivated oyster populations in the Pacific Northwest. Diagn Microbiol Infect Dis 9:1-5.

61. Colwell RR, Huq A. 1994. Vibrios in the environment: viable but non-culturable Vibrio cholerae, p 117-133. In Wachsmuth IK, Blake PA, Olsvik O (ed), Vibrio cholerae and cholera: molecular to global perspectives. American Society for Microbiology, Washington, DC.

62. Montilla R, Chowdhury MA, Huq A, Xu B, Colwell RR. 1996. Serogroup conversion of Vibrio cholerae non-O1 to Vibrio cholerae O1: effect of growth state of cells, temperature, and salinity. Can J Microbiol 42:87-93.

63. Blokesch M, Schoolnik GK. 2007. Serogroup conversion of Vibrio cholerae in aquatic reservoirs. PLoS Pathog 3:e81.

64. Kaspar CW, Tamplin ML. 1993. Effects of temperature and salinity on the survival of Vibrio vulnificus in seawater and shellfish. Appl Environ Microbiol 59:2425-2429.
65. Xu HS, Roberts N, Singleton FL, Attwell RW, Grimes DJ, Colwell RR. 1982. Survival and viability of nonculturable Escherichia coli and Vibrio cholerae in the estuarine and marine environment. Microb Ecol 8:313323.

66. Kimes NE, Grim CJ, Johnson WR, Hasan NA, Tall BD, Kothary MH, Kiss H, Munk AC, Tapia R, Green L, Detter C, Bruce DC, Brettin TS, Colwell RR, Morris PJ. 2012. Temperature regulation of virulence factors in the pathogen Vibrio coralliilyticus. ISME J 6:835846.

67. Oh MH, Lee SM, Lee DH, Choi SH. 2009. Regulation of the Vibrio vulnificus hupA gene by temperature alteration and cyclic AMP receptor protein and evaluation of its role in virulence. Infect Immun 77:12081215.

68. Vezzulli L, Pruzzo C, Huq A, Colwell RR. 2010. Environmental reservoirs of Vibrio cholerae and their role in cholera. Env Microbiol Rep 2:27-33.

69. Pruzzo C, Crippa A, Bertone S, Pane L, Carli A. 1996. Attachment of Vibrio alginolyticus to chitin mediated by chitin binding proteins. Microbiology 142:2181-2186.

70. Long RA, Rowley DC, Zamora E, Liu J, Bartlett DH, Azam F. 2005. Antagonistic interactions among marine bacteria impede the proliferation of Vibrio cholerae. Appl Environ Microbiol 71:85318536.

71. Rypien KL, Ward JR, Azam F. 2010. Antagonistic interactions among coral-associated bacteria. Environ Microbiol 12:28-39.

72. Huq A, Small EB, West PA, Huq MI, Rahman R, Colwell RR. 1983. Ecological relationship between Vibrio cholerae and planktonic copepods. Appl Environ Microbiol 45:275-283.

73. Colwell RR. 1996. Global climate and infectious disease: the cholera paradigm. Science 274:2025-2031.

74. Nelson EJ, Harris JB, Morris JG Jr, Calderwood SB, Camilli A. 2009. Cholera transmission: the host, pathogen and bacteriophage dynamic. Nat Rev Microbiol 7:693-702

75. Pruzzo C, Tarsi R, Lleò MM, Signoretto C, Zampini M, Pane L, Colwell RR, Canepari P. 2003. Persistence of adhesive properties in Vibrio cholerae after long term exposure to sea water. Environ Microbiol 5:850858 .

76. Huq A, West PA, Small EB, Huq MI, Colwell RR. 1984. Influence of water temperature, salinity, and $\mathrm{pH}$ on survival and growth of toxigenic Vibrio cholerae serovar 01 associated with live copepods in laboratory microcosms. Appl Environ Microbiol 48:420-424.

77. Turner JW, Good B, Cole D, Lipp EK. 2009. Plankton composition and environmental factors contribute to Vibrio seasonality. ISME J 3:1082-1092.

78. Stauder M, Vezzulli L, Pezzati E, Repetto B, Pruzzo C. 2010. Temperature affects Vibrio cholerae $\mathrm{O} 1 \mathrm{El}$ Tor persistence in the aquatic environment via an enhanced expression of GbpA and MSHA adhesins. Env Microbiol Rep 2:140-144.

79. Stauder M, Huq A, Pezzati E, Grim CJ, Ramoino P, Pane L, Colwell RR, Pruzzo C, Vezzulli L. 2012. Role of GbpA protein, an important virulence-related colonization factor, for Vibrio cholerae's survival in the aquatic environment. Environ Microbiol Rep 4:439-445.

80. Colwell RR. 2002. A voyage of discovery: cholera, climate and complexity. Environ Microbiol 4:67-69.

81. Moran XAG, Lopez-Urrutia A, Calvo-Diaz A, Li WKW. 2010. Increasing importance of small phytoplankton in a warmer ocean. Glob Chang Biol 16:1137-1144.

82. Beaugrand G, Reid PC, Ibañez F, Alistair Lindley J, Edwards M. 2002. Reorganization of North Atlantic marine copepod biodiversity and climate. Science 296:1692-1694

83. Reid PC, Gorick G, Edwards M. 2011. Climate change and European Marine Ecosystem Research. Sir Alister Hardy Foundation for Ocean Science, Plymouth, UK. 
84. Richardson AJ. 2008. In hot water: zooplankton and climate change. ICES J Mar Sci 65:279-295.

85. Martinez-Urtaza J, Huapaya B, Gavilan RG, Blanco-Abad V, Ansede-Bermejo J, Cadarso-Suarez C, Figueiras A, Trinanes J. 2008. Emergence of Asiatic Vibrio diseases in South America in phase with El Niño. Epidemiology 19:829-837.

86. Rawlings TK, Ruiz GM, Colwell RR. 2007. Association of Vibrio cholerae serogroups O1 El Tor and O139 Bengal with the copepods Acartia tonsa and Eurytemora affinis. Appl Environ Microbiol 73:7926-7933.
87. Reid PC, Colebrook JM, Matthews JBL, Aiken J. 2003. The continuous plankton recorder: concepts and history, from plankton indicator to undulating recorders. Prog Oceanogr 58:117-173.

88. Anderson MJ. 2003. DISTLM forward: a FORTRAN computer program to calculate a distance-based multivariate analysis for a linear model using forward selection. Department of Statistics, University of Auckland, Auckland, New Zealand.

89. Bowler C, Karl DM, Colwell RR. 2009. Microbial oceanography in a sea of opportunity. Nature 459:180-184. 